Zeszyty Naukowe Szkoły Głównej Gospodarstwa Wiejskiego w Warszawie

Problemy Rolnictwa Światowego tom 18 (XXXIII), zeszyt 2, 2018: 280-290

DOI: $10.22630 /$ PRS.2018.18.2.55

Aldona Skarżyńska ${ }^{1}$

Instytut Ekonomiki Rolnictwa i Gospodarki Żywnościowej - Państwowy Instytut Badawczy

\title{
Wykorzystanie czynników produkcji w gospodarstwach specjalizujących się $w$ chowie bydła rzeźnego w wybranych krajach Unii Europejskiej
}

\section{The Use of Production Factors in Farms Specializing in Production of Fattening Cattle in Selected European Union Countries}

\begin{abstract}
Synopsis. Celem badań była ocena wykorzystania czynników produkcji w gospodarstwach specjalizujących się w chowie bydła rzeźnego w sześciu krajach, które są największymi producentami wołowiny w UE-15 (we Francji, Niemczech, Włoszech, Wielkiej Brytanii, Hiszpanii i Irlandii) i w dwóch krajach zaliczanych do UE-N13 (w Polsce i Rumunii). W badaniach wykorzystano dane FADN EU średnie w latach 2010-2015. Zbadano produktywność i dochodowość czynników wytwórczych, sprawność ekonomiczną produkcji oraz uzależnienie gospodarstw od dopłat. Wyniki wskazuja na przewage producentów wołowiny we Włoszech, Hiszpanii, Rumunii i w Polsce. W gospodarstwach we Francji, Niemczech, Wielkiej Brytanii i Irlandii koszty były wyższe od wartości produkcji, w efekcie dochód był ujemny. Stratę pokryły dopłaty, miały też wpływ na wysokość dochodu, jego poziom nie wynikał jednak z wysokiej efektywności produkcji.
\end{abstract}

Słowa kluczowe: produkcja wołowiny, czynniki produkcji, efektywność, dopłaty

\begin{abstract}
The aim of the study was to assess the use of production factors in farms specializing in production of cattle for fattening in six countries, which are the biggest producers of beef in the EU-15 (in France, Germany, Italy, Great Britain, Spain and Ireland) and in two countries included in the EU N13 (in Poland and Romania). The research used FADN EU average data in 2010-2015. The productivity and profitability of production factors, the economic efficiency of production and the dependence of farms on subsidies were examined. The results indicate an advantage of beef producers in Italy, Spain, Romania and Poland. In farms in France, Germany, Great Britain and Ireland, the costs were higher than the value production, as a result the income was a negative value. The loss was covered by subsidies, which also influenced the amount of income, but its level did not result from high production efficiency.
\end{abstract}

Key words: beef production, factors of production, efficiency, subsidies

JEL Classification: Q12, Q14, Q19

\section{Wprowadzenie}

Rynek mięsa wołowego jest trzecim segmentem światowego rynku mięsa, po wieprzowinie i mięsie drobiowym. W latach 80-tych XX wieku mięso wołowe zajmowało drugie miejsce ale straciło tę pozycję na rzecz mięsa drobiowego (Rycombel, Zawadzka i Wierzbicka, 2012). Na rynku światowym, od kilku lat kraje UE-28 (łącznie) zajmują trzecie miejsce (po USA i Brazylii) pod względem ilości produkowanej wołowiny (Pasińska, 2016).

${ }^{1}$ dr hab. inż. prof. IERIGŻ-PIB, Zakład Rachunkowości Rolnej, IERiGŻ-PIB, ul. Świętokrzyska 20, 00-002 Warszawa, e-mail: aldona.skarzynska@ierigz.waw.pl 
Główni producenci to kraje „starej Unii” (UE-15), średnio w latach 2010-2016, ich łączna produkcja w przeliczeniu na wagę mięsa (tzw. wagę bitą ciepłą - wbc) stanowiła 89,7\% w ogólnej produkcji UE-28 (7776 tys. ton). Oznacza to, że na kraje, które przystapiły do UE po 2004 roku (UE-N13) przypadało zaledwie 10,3\% (802 tys. ton). Wśród krajów UE-15 najwięksi producenci wołowiny (łącznie z cielęcina) to Francja, Niemcy, Włochy, Wielka Brytania, Hiszpania i Irlandia. Średnio w latach 2010-2016 ich łączna produkcja w przeliczeniu na wagę mięsa (wbc) stanowiła 72,0\% ogólnej produkcji w krajach UE-15. Natomiast Polska i Rumunia to najwięksi producenci wołowiny (łącznie z cielęciną) wśród krajów EU-N13, ich łączna produkcja stanowiła 64,2\%. Należy dodać, że Polska w unijnej produkcji wołowiny zajmowała miejsce siódme (po Irlandii), a Rumunia - trzynaste. W pozostałych krajach produkcja wołowiny była niewielka, zawierała się w przedziale 1-89 tys. ton wbc, odpowiednio na Malcie i w Portugalii (European Commission, 2018).

W niektórych krajach, np. w Polsce nie ma tradycji chowu bydła ras mięsnych, dlatego produkcja wołowiny w większości powiązana jest z mlecznym kierunkiem użytkowania bydła. Podobne zjawisko, co w Polsce, można zaobserwować w całej UE, szacuje się, że około dwie trzecie produkowanej wołowiny pochodzi od zwierząt ze stad krów mlecznych. Z tego względu sektor mleczny i zachodzące zmiany w pogłowiu bydła, wynikające m.in. ze zniesienia kwot mlecznych oraz wahań ceny mleka, mają duży wpływ na podaż mięsa wołowego (European Commission, 2016). Chów bydła opasowego jest alternatywą dla produkcji mleka. Dotyczy to szczególnie gospodarstw posiadających znaczny areał użytków zielonych i ziemi słabo wykorzystywanej, czasami leżącej odłogiem. Rolnicy, którzy utrzymywali bydło mleczne i nie sprostali konkurencji, powinni zainteresować się tym kierunkiem produkcji, aby wykorzystać wolne pomieszczenia i rezerwy paszowe powstałe w wyniku ograniczenia chowu bydła mlecznego (Nogalski i Wroński, 2011).

Analiza systemu płatności bezpośrednich i dochodów gospodarstw rolnych pokazuje, że przeciętnie unijni producenci wołowiny są bardzo uzależnieni od płatności w ramach WPR, nawet w ponad 100\%. Fakt ten budzi pewne obawy odnośnie przyszłości gospodarstw z tego sektora (European Parliament, 2017).

Celem badań była ocena wykorzystania czynników produkcji oraz pokazanie efektywności produkcji w gospodarstwach rolnych specjalizujących się w chowie bydła rzeźnego w 8 krajach (Francji, Niemczech, Włoszech, Wielkiej Brytanii, Hiszpanii, Irlandii oraz w Polsce i Rumunii), które są dużymi producentami wołowiny w UE. Przeprowadzona analiza jest interesująca dla Polski, jako kraju, który w produkcji wołowiny, wśród państw zaliczanych do UE-N13, zajmował pozycję pierwszą, a siódmą wśród zaliczanych do UE-28 (średnio w latach 2010-2016). Interesująca jest również z tego względu, że w ostatnich latach można zaobserwować wzrost pogłowia młodego bydła (w roku 2016 w porównaniu z rokiem 2010 o 33,5\%), co wskazuje na rozwój tego sektora, a tym samym większą produkcję wołowiny (GUS, 2011 i GUS, 2017).

\section{Dane i metody}

Przedmiotem badań były gospodarstwa specjalizujące się w chowie bydła rzeźnego (typ 49) w sześciu krajach, które są największymi producentami wołowiny wśród krajów UE-15 (we Francji, Niemczech, Włoszech, Wielkiej Brytanii, Hiszpanii i Irlandii) i w dwóch krajach zaliczanych do UE-N13 (w Polsce i Rumunii). Za kryterium wyboru tych krajów przyjęto łączny ich udział w produkcji wołowiny w UE-15 i UE-N13. Do analizy 
wykorzystano najbardziej aktualne i dostępne dane podczas prowadzania analiz, tj. za lata 2010-2015, zebrane i przetworzone w ramach systemu FADN EU (Farm Accountancy, 2017).

Wyniki gospodarstw w układzie tabelarycznym przedstawiono jako średnie w latach 2010-2015. W badaniach wykorzystano analizę poziomą porównując parametry charakteryzujące gospodarstwa $\mathrm{w}$ poszczególnych krajach. Analizie poddano potencjał produkcyjny gospodarstw, tj. powierzchnię użytków rolnych (UR), zasoby pracy wyrażone liczbą osób pełnozatrudnionych $(\mathrm{AWU})^{2}$ oraz aktywa ogółem ${ }^{3}$. Zbadano także strukturę aktywów i organizację produkcji w gospodarstwach.

Efektywność wykorzystania czynników produkcji, tj. pracy, ziemi i kapitału mierzono produktywnością i dochodowością tych czynników. Miarą nakładów czynnika ziemi była powierzchnia użytków rolnych (SE025), czynnika pracy - jednostki AWU (SE020), a czynnika kapitału - średnia arytmetyczna wartość kapitału gospodarstwa rolnego (SE510). Produktywność ustalono odnosząc wartość produkcji (SE131), a dochodowość wartość dodaną netto (SE415) pomniejszoną o dopłaty do działalności operacyjnej gospodarstwa (SE605), do nakładów poszczególnych czynników produkcji.

Ocenę efektywności produkcji scharakteryzowano za pomocą wskaźników:

- $\quad$ udział nadwyżki bezpośredniej ${ }^{4} \mathrm{w}$ wartości produkcji - efektywność na poziomie produkcyjno-technicznym (Kulawik, 2013 za: Dabbert i Braun, 2012),

- relacja wartości dodanej brutto (bez dopłat) do wartości produkcji ogółem - sprawność ekonomiczna produkcji (Czyżewski i Henisz-Matuszczak, 2007),

- relacja wartości dodanej brutto (bez dopłat) do zużycia pośredniego - dochodowość nakładów środków obrotowych mierzonych wartością zużycia pośredniego,

- relacja amortyzacji do wartości dodanej netto bez dopłat - kapitałochłonność produkcji,

- koszty ogółem wytworzenia 100 euro produkcji-kosztochłonność produkcji.

Ocenie poddano także uzależnienie gospodarstw od wsparcia dopłat do działalności operacyjnej. Określono więc wpływ WPR na efekty ekonomiczne gospodarstw.

\section{Charakterystyka badanych gospodarstw}

$\mathrm{Z}$ danych zawartych $\mathrm{w}$ tabeli 1 wynika, że wielkość ekonomiczna gospodarstw specjalizujących się w chowie bydła rzeźnego w krajach ujętych w badaniach była bardzo zróżnicowana. Gospodarstwa w krajach zaliczanych do UE-15 charakteryzowały się znacznie większą siłą ekonomiczną niż w krajach UE-N13. Porównując skrajne wartości (Niemcy - 122,4, Rumunia - 7,8 tys. EUR) zróżnicowanie było prawie 16-krotne.

\footnotetext{
${ }^{2}$ AWU - Całkowite nakłady pracy ludzkiej w ramach działalności operacyjnej gospodarstwa rolnego wyrażone $\mathrm{w}$ jednostkach przeliczeniowych pracy, $\mathrm{tj}$. w osobach pełnozatrudnionych.

${ }^{3}$ Aktywa gospodarstwa dzieli się na trwałe i obrotowe. Aktywa trwale obejmują: ziemię rolnicza, uprawy trwałe i kwoty produkcyjne, budynki gospodarstwa i ich trwałe wyposażenie, maszyny, urządzenia i środki transportu oraz zwierzęta stada podstawowego płci żeńskiej. Aktywa obrotowe obejmują: wartość wszystkich zwierząt produkcyjnych (poza zwierzętami stada podstawowego, zapasy produktów rolnych, wartość upraw na pniu, udziały gospodarstwa w jednostkach rolniczych, należności krótkoterminowe oraz gotówkę w kasie i na rachunku bankowym w kwocie niezbędnej do bieżącego funkcjonowania gospodarstwa rolnego.

${ }^{4}$ Nadwyżka bezpośrednia = wartość produkcji ogółem gospodarstwa pomniejszona o wartość kosztów bezpośrednich produkcji roślinnej i zwierzęcej oraz o wartość kosztów bezpośrednich produkcji leśnej.
} 
Wyposażenie gospodarstw w czynniki produkcji także było różne. Średnio w latach 2010-2015 najmniej zróżnicowane były zasoby pracy - tylko 1,4-krotnie, największe odnotowano $\mathrm{w}$ gospodarstwach francuskich (1,50 AWU), a najmniejsze - w irlandzkich (1,05 AWU). Różnice pod względem pracochłonności produkcji były większe, na 100 ha UR najwięcej tego czynnika produkcji przypadało w Rumunii - 21,43 AWU, a najmniej we Francji - 1,37 AWU. Oznacza to, że w Rumunii pracochłonność produkcji była 15,6-krotnie większa. Gospodarstwa we wszystkich krajach korzystały z pracy najemnej - w największym stopniu w Niemczech, a w najmniejszym w Irlandii, świadczy o tym udział nakładów pracy własnej (FWU) w nakładach pracy ogółem (AWU), który wynosił odpowiednio 83,4 i 97,3\%.

Tabela 1. Charakterystyka gospodarstw specjalizujących się w chowie bydła rzeźnego w wybranych krajach UE średnio w latach 2010-2015

Table 1. Characteristics of farms specializing in production of fattening cattle in selected EU countries on average in 2010-2015

\begin{tabular}{|c|c|c|c|c|c|c|c|c|c|}
\hline \multicolumn{2}{|c|}{ Wyszczególnienie } & FR & $\mathrm{DE}$ & IT & GB & ES & IE & PL & RO \\
\hline $\begin{array}{l}\text { Wielkość ekonom. } \\
\text { gospodarstw }\end{array}$ & tys. EUR & 98,2 & 122,4 & 71,0 & 88,2 & 48,9 & 23,8 & 17,9 & 7,8 \\
\hline $\begin{array}{l}\text { Pow. użytków rolnych } \\
\text { (UR) }\end{array}$ & ha & 109,76 & 67,38 & 35,31 & 104,49 & 65,35 & 40,56 & 17,24 & 6,07 \\
\hline $\begin{array}{l}\text { Udział UR } \\
\text { dzierżawionych }\end{array}$ & proc. & 80,8 & 64,8 & 63,9 & 36,6 & 49,8 & 15,4 & 23,0 & 26,5 \\
\hline $\begin{array}{l}\text { Liczba osób } \\
\text { pełnozatrudnionych }\end{array}$ & AWU & 1,50 & 1,45 & 1,31 & 1,46 & 1,30 & 1,05 & 1,48 & 1,30 \\
\hline $\begin{array}{l}\text { w tym: udział pracy } \\
\text { własnej (FWU) }\end{array}$ & proc. & 92,7 & 83,4 & 90,0 & 84,2 & 90,0 & 97,3 & 96,6 & 93,1 \\
\hline $\begin{array}{l}\text { Liczba osób na } 100 \text { ha } \\
\text { UR }\end{array}$ & AWU & 1,37 & 2,15 & 3,72 & 1,40 & 1,98 & 2,60 & 8,60 & 21,43 \\
\hline Aktywa ogółem & EUR/gosp. & 423508 & 660270 & 524989 & 1263050 & 326605 & 766037 & 142384 & 30661 \\
\hline w tym: aktywa trwałe & proc. & 67,6 & 85,6 & 62,3 & 90,2 & 70,7 & 91,7 & 88,7 & 81,1 \\
\hline $\begin{array}{l}\text { Udział ziemi } \\
\text { w aktywach trwałych }\end{array}$ & proc. & 16,9 & 71,2 & 70,1 & 85,9 & 66,4 & 88,7 & 59,3 & 34,2 \\
\hline $\begin{array}{l}\text { Pozostałe bydło na } 100 \\
\text { ha UR }\end{array}$ & LU & 102,0 & 99,0 & 118,6 & 95,8 & 75,1 & 102,8 & 71,1 & 52,7 \\
\hline $\begin{array}{l}\text { Udział prod. zwierz. w } \\
\text { wart. prod. gosp. }\end{array}$ & proc. & 86,3 & 69,5 & 69,8 & 71,2 & 83,2 & 82,2 & 68,2 & 61,6 \\
\hline
\end{tabular}

Średni obszar użytków rolnych (UR) w badanych gospodarstwach zawierał się w granicach 6,07-109,76 ha, najmniejsze pod względem zasobów ziemi były gospodarstwa rumuńskie, a największe - francuskie. Użytki rolne znajdujące się w gospodarstwach francuskich były jednak w najmniejszym stopniu zasobem własnym rodzin rolniczych -

\footnotetext{
5 Zasoby gospodarstw celowo zaangażowane w proces produkcji i aktywnie w nim uczestniczące nazywane są czynnikami produkcji. Pojęcie to obejmuje pracę (zasoby ludzkie), ziemię oraz kapitał. W ujęciu ilościowym czynniki te określają wielkość zatrudnienia, obszar ziemi oraz wartość obrotowych i trwałych środków produkcyjnych (Woś, 1996).
} 
udział UR dzierżawionych wynosił aż 80,8\%. Natomiast najmniejszy udział ziemi obcej odnotowano w gospodarstwach irlandzkich $-15,4 \%$.

Ważny jest także majątek gospodarstw (aktywa). W aktywach ogółem, przeważały aktywa trwałe, ich udział największy był w gospodarstwach z Irlandii (91,7\%) i Wielkiej Brytanii $(90,2 \%)$, a najmniejszy $\mathrm{z}$ Włoch $(62,3 \%)$ i Francji $(67,6 \%)$. W gospodarstwach prawie wszystkich krajów w wartości aktywów trwałych utrzymywał się wysoki udział ziemi, wyjątkiem były tylko gospodarstwa francuskie, w których udział ziemi wynosił 16,9\%. Wynika to jednak ze struktury własnościowej ziemi. Zdominowanie majątku gospodarstw przez aktywa trwałe jest charakterystyczną cechą gospodarstw rolnych, w których występuje większe zapotrzebowanie na środki trwałe niż w przedsiębiorstwach z sektora pozarolniczego.

Pogłowie zwierząt zaliczanych do grupy „pozostałe bydło” (pogłowie bydła niemlecznego) przypadające na 100 ha użytków rolnych, wskazuje na intensywność organizacji produkcji zwierzęcej. Z obliczeń wynika, że w Rumunii, w Polsce i w Hiszpanii liczba zwierząt (wyrażonych w jednostkach przeliczeniowych zwierząt LU) była najmniejsza, wynosiła kolejno 52,7, 71,1 i 75,1 jednostek LU. Natomiast największa była we Francji, Irlandii i we Włoszech, wynosiła odpowiednio 102,0, 102,8 i 118,6 LU. W strukturze wartości produkcji gospodarstw, we wszystkich krajach przeważała produkcja zwierzęca. W Irlandii, Hiszpanii i Francji jej udział był największy - wynosił od 82,2 do $86,3 \%$, w pozostałych krajach był mniejszy i podobny względem siebie, zawierał się w granicach 61,6-71,2\% - tabela 1.

\section{Efektywność wykorzystania czynników produkcji}

Z obliczeń zawartych w tabeli 2 wynika, że pod względem produktywności ziemi gospodarstwa polskie zajęły pozycję drugą od końca. Wartość produkcji liczona na 1 ha użytków rolnych wynosiła 794 EUR i o $21,4 \%$ przewyższała najniższy jej poziom w gospodarstwach hiszpańskich (654 EUR). Natomiast w porównaniu do najwyższej produktywności ziemi gospodarstw włoskich (2004 EUR/ha UR) - była niższa o 60,4\%. Na wysokość tego wskaźnika wpływ miała między innymi intensywność organizacji produkcji zwierzęcej, wydajność techniczna produkcji i ceny sprzedaży produktów.

Gospodarstwa polskie zajęły także drugą pozycję od końca pod względem produktywności pracy, która wynosiła 9,2 tys. EUR/AWU. Najwyższą produktywność pracy osiagnęly gospodarstwa niemieckie (80,5 tys. EUR/AWU), a najniższą rumuńskie (6,1 tys. EUR/AWU). Rozpiętość tego wskaźnika była 13,2-krotna, decydujący wpływ na poziom produktywności pracy miały przychody gospodarstw.

Produktywność kapitału najniższa była $\mathrm{w}$ gospodarstwach polskich, a najwyższa w niemieckich - wynosiła odpowiednio 20 i 45 EUR/100 EUR kapitału. Różnica na niekorzyść Polski była 2,2-krotna, zadecydowały o tym przychody, które w porównaniu do gospodarstw niemieckich były niższe 8,5-krotnie (średnia wartość kapitału była niższa 3,8-krotnie).

Struktura własnościowa czynników wytwórczych w gospodarstwach z próby badawczej była bardzo zróżnicowana. Najmniej obciążone kosztem użycia obcych czynników wytwórczych, biorąc pod uwagę udział w kosztach ogółem były gospodarstwa polskie i irlandzkie, a najbardziej obciążone były gospodarstwa francuskie i niemieckie. Udział kosztu czynników zewnętrznych w kosztach ogółem w gospodarstwach w Polsce i Irlandii wynosił odpowiednio 6,1 i 6,9\%, a we Francji i w Niemczech odpowiednio 12,5 i 14,0\%. 
W sytuacji występowania dużych różnic w zakresie własności czynników wytwórczych, do analizy wyników ekonomicznych gospodarstw rolnych odpowiednia jest wartość dodana netto. Kategoria ta jest miarą dochodu nadającą się do analizy wyników ekonomicznych gospodarstw niezależnie od sytuacji w zakresie własności czynników wytwórczych. Wartość dodana netto odzwierciedla zrealizowaną opłatę czynników wytwórczych, tj. pracy, ziemi i kapitału bez względu na to kto jest ich właścicielem. Na tym etapie rachunku eliminowany jest wpływ na wyniki kosztu czynników zewnętrznych, czyli pracy najemnej, czynszu dzierżawnego i odsetek od kredytów (Goraj i Mańko, 2004). Rachunek opiera się na założeniu, że wszystkie środki produkcji i kapitał stanowią własność rolnika.

Według literatury przedmiotu, im większy efekt przypada na jednostkę nakładu, tym większa jest efektywność (Kulawik, 2007). Badając efektywność użytych w procesie produkcji zasobów można określić sprawność gospodarowania. Jest to ważne zagadnienie, ponieważ potencjał produkcyjny gospodarstw oraz sprawność gospodarowania silnie oddziałują na poziom dochodów.

Tabela 2. Produktywność i dochodowość czynników produkcji w gospodarstwach specjalizujących się w chowie bydła rzeźnego w wybranych krajach UE średnio w latach 2010-2015

Table 2. Productivity and profitability of production factors in farms specializing in production of fattening cattle in selected EU countries on average in 2010-2015

\begin{tabular}{|c|c|c|c|c|c|c|c|c|c|}
\hline Wyszczególnienie & & FR & $\mathrm{DE}$ & IT & GB & ES & IE & PL & $\mathrm{RO}$ \\
\hline \multirow{4}{*}{$\begin{array}{l}\text { Wartość produkcji } \\
\text { ogółem }\end{array}$} & EUR/gosp. & 109167 & 116897 & 70755 & 114067 & 42710 & 32940 & 13692 & 7935 \\
\hline & EUR/ha UR & 995 & 1735 & 2004 & 1092 & 654 & 812 & 794 & 1307 \\
\hline & EUR/AWU & 72778 & 80526 & 53874 & 78128 & 32981 & 31272 & 9241 & 6096 \\
\hline & $\begin{array}{l}\text { EUR/100 } \\
\text { EUR kapitału }\end{array}$ & 29 & 45 & 28 & 38 & 24 & 21 & 20 & 35 \\
\hline \multirow{4}{*}{$\begin{array}{l}\text { Wartość dodana } \\
\text { netto pomniejszona } \\
\text { o dopłaty do } \\
\text { działalności } \\
\text { operacyjnej } \\
\text { gospodarstwa }\end{array}$} & EUR/gosp. & -4502 & 7103 & 22556 & -583 & 6907 & -2101 & 840 & 2799 \\
\hline & EUR/ha UR & -41 & 105 & 639 & -6 & 106 & -52 & 49 & 461 \\
\hline & EUR/AWU & -3001 & 4893 & 17175 & -400 & 5333 & -1994 & 567 & 2150 \\
\hline & $\begin{array}{l}\text { EUR/100 } \\
\text { EUR kapitału }\end{array}$ & $-1,20$ & 2,74 & 8,84 & $-0,19$ & 3,80 & $-1,34$ & 1,23 & 12,48 \\
\hline $\begin{array}{l}\text { Koszt czynników } \\
\text { zewnętrznych (kcz) }\end{array}$ & EUR/gosp. & 15982 & 17867 & 5114 & 12910 & 4274 & 2498 & 803 & 498 \\
\hline $\begin{array}{l}\text { Udział kcz } \\
\text { w kosztach gosp. }\end{array}$ & proc. & 12,5 & 14,0 & 9,9 & 10,2 & 10,6 & 6,9 & 6,1 & 9,0 \\
\hline $\begin{array}{l}\text { Średnia wartość } \\
\text { kapitału gosp. }\end{array}$ & EUR/gosp. & 374150 & 258961 & 255072 & 300813 & 181584 & 156274 & 68263 & 22428 \\
\hline
\end{tabular}

Objaśnienia: FR - Francja, DE - Niemcy, IT - Włochy, GB - Wielka Brytania, ES - Hiszpania, IE - Irlandia, PL - Polska, RO - Rumunia.

Źródło: opracowano na podstawie badań własnych.

Wartość dodana netto gospodarstw specjalizujących się w chowie bydła rzeźnego, w krajach o największej produkcji wołowiny w UE była bardzo zróżnicowana. W trzech krajach wartość dodana netto była wartością ujemną. Największą stratę poniosły gospodarstwa francuskie (-4,5 tys. EUR/gosp.), strata jednostek z Irlandii była mniejsza o 53,3\% (-2,1 tys. EUR/gosp.), a z Wielkiej Brytanii o 87,1\% (-583 EUR/gosp.). Sytuacja 
ekonomiczna tych gospodarstw była niekorzystna, zwrot $\mathrm{z}$ zaangażowania czynników wytwórczych (tj. ziemi, pracy i kapitału) w proces produkcji nie został zrealizowany.

$\mathrm{W}$ pozostałych krajach z próby badawczej dochodowość ziemi, której miarą była wartość dodana netto przypadająca na 1 ha UR, najwyższa była w gospodarstwach we Włoszech i Rumunii, wynosiła odpowiednio 639 i 461 EUR. W gospodarstwach kolejnych krajów była niższa, w Hiszpanii wynosiła 106 EUR, w Niemczech 105 EUR, a w Polsce 49 EUR. Porównując skrajne wartości różnica była 13-krotna.

Rozpiętość wskaźnika, który odzwierciedla ekonomiczną wydajność pracy (wartość dodana netto przypadająca na 1 AWU) była bardzo duża - aż 30,3-krotna. W najlepszej sytuacji były gospodarstwa specjalizujące się w chowie bydła rzeźnego we Włoszech (17,2 tys. EUR/AWU), a w najsłabszej - w Polsce (567 EUR/AWU). Wartość dodana netto przypadająca na 1 AWU w gospodarstwach polskich była bardzo niska, co wskazuje na relatywnie niższy poziom życia rolników.

Dochodowość kapitału charakteryzuje 10,1-krotne zróżnicowanie wynikające z porównania wartości skrajnych. Wartość dodana netto przypadająca na 100 EUR kapitału w gospodarstwach rumuńskich była najwyższa - wynosiła 12,48 EUR, dość wysoka była także w gospodarstwach włoskich $-8,84$ EUR. Natomiast w gospodarstwach niemieckich i polskich była najniższa, wynosiła odpowiednio 2,74 i 1,23 EUR.

Wyniki badań wskazują na przewagę gospodarstw włoskich pod względem dochodowości ziemi i pracy ale także kapitału, podczas gdy sytuacja gospodarstw polskich była relatywnie słaba. Ocenia się, że na efektywność procesu produkcji pewien wpływ miały relacje między czynnikami wytwórczymi. Posiadanie dużych zasobów produkcyjnych jest atutem, ale ich nadmiar sprawia, że nie zawsze są w pełni, czy w najlepszy sposób wykorzystywane.

\section{Efektywność produkcji}

Analizując sprawność funkcjonowania gospodarstw, w badaniach wykorzystano wskaźnik udziału nadwyżki bezpośredniej w wartości produkcji, a wiec relacji oddającej efektywność na poziomie produkcyjno-technicznym. W gospodarstwach specjalizujących się w chowie bydła rzeźnego w Hiszpanii, Wielkiej Brytanii oraz Irlandii wskaźnik ten zawierał się w granicach 40,7-45,8\%. Jego wysokość wskazuje, że ww. efektywność była relatywnie mała. W gospodarstwach w pozostałych krajach udział nadwyżki bezpośredniej w wartości produkcji wynosił od $59,1 \%$ do $63,3 \%$, co oznacza większą efektywność na poziomie produkcyjno-technicznym - tabela 3.

Relacja wartości dodanej brutto (bez dopłat) do wartości produkcji ogółem odzwierciedla sprawność ekonomiczną produkcji. Przeprowadzona analiza wskazuje, że w gospodarstwach z Irlandii i Wielkiej Brytanii (podobnie jak efektywność produkcyjnotechniczna) bardzo niska była też sprawność ekonomiczna produkcji. Jednostka produkcji ogółem generowała odpowiednio 0,09 i 0,16 jednostki wartości dodanej brutto. Trochę wyższy był wskaźnik sprawności produkcji we Francji $(0,20)$, Niemczech $(0,23)$ i Hiszpanii $(0,24)$. W gospodarstwach polskich sytuacja była korzystniejsza, z jednostki wartości produkcji ogółem rolnicy uzyskali 0,30 jednostki wartości dodanej brutto. Natomiast w gospodarstwach włoskich i rumuńskich ekonomiczna sprawność produkcji była najwyższa, wskaźnik wynosił odpowiednio 0,43 i 0,46 . Na tym etapie wnioskowania wyraźnie widać, że sprawność ekonomiczna produkcji nie wykazuje związku 
z powierzchnią użytków rolnych. W jednostkach obszarowo największych (Wielka Brytania, Francja) sprawność ekonomiczna produkcji była gorsza niż w gospodarstwach obszarowo mniejszych (Rumunia, Polska, Włochy).

Odnosząc wartość dodaną brutto do nakładów środków obrotowych mierzonych wartością zużycia pośredniego okazało się, że wskaźnik dochodowości ww. nakładów najkorzystniej kształtował się w gospodarstwach rumuńskich i włoskich, a następnie polskich, wynosił kolejno 86,9, 80,2 i 44,5\%. Znacznie niższą i zbliżoną względem siebie dochodowość nakładów obrotowych osiagnęły gospodarstwa hiszpańskie (31,9\%), niemieckie $(29,5 \%)$ i francuskie $(25,6 \%)$. Natomiast w gospodarstwach specjalizujących się w chowie bydła rzeźnego w Wielkiej Brytanii i Irlandii dochodowość nakładów środków obrotowych była najmniejsza, wynosiła odpowiednio 19,3 i 10,3\%.

Tabela 3. Efektywność produkcji w gospodarstwach specjalizujących się w chowie bydła rzeźnego w wybranych krajach UE średnio w latach 2010-2015

Table 3. Production efficiency in farms specializing in production of fattening cattle in selected EU countries on average in $2010-2015$

\begin{tabular}{|c|c|c|c|c|c|c|c|c|c|}
\hline Wyszczególnienie & & FR & $\mathrm{DE}$ & IT & GB & ES & $\mathrm{IE}$ & PL & $\mathrm{RO}$ \\
\hline $\begin{array}{l}\text { Relacja nadwyżki bezpośredniej } \\
\text { do wartości produkcji }\end{array}$ & proc. & 61,1 & 60,0 & 59,1 & 45,2 & 40,7 & 45,8 & 61,3 & 63,3 \\
\hline $\begin{array}{l}\text { Relacja wartości dodanej brutto } \\
\text { bez dopłat do wartości produkcji }\end{array}$ & & 0,20 & 0,23 & 0,43 & 0,16 & 0,24 & 0,09 & 0,30 & 0,46 \\
\hline $\begin{array}{l}\text { Relacja wart. dodanej brutto bez } \\
\text { dopłat do zużycia pośredniego }\end{array}$ & proc. & 25,6 & 29,5 & 80,2 & 19,3 & 31,9 & 10,3 & 44,5 & 86,9 \\
\hline $\begin{array}{l}\text { Relacja amortyzacji do wartości } \\
\text { dodanej netto bez dopłat }\end{array}$ & & $-5,88$ & 2,73 & 0,36 & $-32,46$ & 0,50 & $-2,41$ & 3,88 & 0,30 \\
\hline $\begin{array}{l}\text { Koszty ogółem wytworzenia } \\
100 \text { euro produkcji }\end{array}$ & EUR & 117 & 109 & 73 & 111 & 94 & 110 & 97 & 69 \\
\hline
\end{tabular}

Objaśnienia: FR - Francja, DE - Niemcy, IT - Włochy, GB - Wielka Brytania, ES - Hiszpania, IE - Irlandia, PL - Polska, RO - Rumunia.

Źródło: opracowano na podstawie badań własnych

Analiza relacji amortyzacji do wartości dodanej netto wykazała, że gospodarstwa z Wielkiej Brytanii były najbardziej kapitałochłonne wśród badanych, następne pozycje zajęły gospodarstwa francuskie i irlandzkie. W tych krajach pomimo dużych nakładów kapitału nie wypracowano dodatniego dochodu na poziomie wartości dodanej netto. W Wielkiej Brytanii nakład 32 jednostek kapitału trwałego przynosił jednostkową stratę. Podobna sytuacja wystapiła we Francji i Irlandii, nakład kolejno 6 i 2 jednostek kapitału również przyniósł stratę. Można przypuszczać, że nastąpiła substytucja pracy przez kapitał, świadczy o tym pracochłonność produkcji, która w gospodarstwach w Wielkiej Brytanii i Francji była najmniejsza (1,40 i 1,37 AWU na 100 ha UR), a w Irlandii - też dość mała (2,60 AWU na 100 ha UR). W próbie gospodarstw polskich wypracowanie jednostki wartości dodanej netto wymagało nakładu prawie 4 jednostek kapitału trwałego. Natomiast najmniej kapitałochłonną produkcję prowadziły gospodarstwa rumuńskie, włoskie i hiszpańskie. W tych krajach wytworzenie jednostki wartości dodanej netto wymagało odpowiednio: 0,30, 0,36 i 0,50 jednostek nakładu kapitału trwałego.

Koszt wytworzenia 100 euro produkcji wskazuje na relatywnie małą kosztochłonność produkcji w gospodarstwach ukierunkowanych na chów bydła rzeźnego w Rumunii i Włoszech (odpowiednio 69 i 73 EUR), a następnie w Hiszpanii i w Polsce (odpowiednio 
94 i 97 EUR). W gospodarstwach pozostałych krajów wytworzenie 100 euro produkcji kosztowało powyżej 100 EUR. Kolejność krajów była następująca: Niemcy (109 EUR), Irlandia (110 EUR), Wielka Brytania (111 EUR) i Francja (117 EUR) - tabela 3.

\section{Uzależnienie gospodarstw od dopłat}

Dane zawarte w tabeli 4 pokazują różny stopień uzależnienia gospodarstw rolnych od dopłat do działalności operacyjnej. Relacja tych dopłat do wartości produkcji zawierała się w granicach od 19,3\% we Włoszech do 54,0\% w Irlandii. Gospodarstwa polskie wskaźnik ten ulokował na miejscu drugim od końca, relacja ta wynosiła $42,9 \%$.

Tabela 4. Uzależnienie od dopłat do działalności operacyjnej gospodarstw specjalizujących się w chowie bydła rzeźnego w wybranych krajach UE średnio w latach 2010-2015

Table 4. Dependence on subsidies to operating activity of farms specializing in production of fattening cattle in selected EU countries on average in 2010-2015

\begin{tabular}{|c|c|c|c|c|c|c|c|c|}
\hline Wyszczególnienie & FR & $\mathrm{DE}$ & IT & GB & ES & IE & PL & RO \\
\hline $\begin{array}{c}\text { Relacja (\%) dopłat do: } \\
\text { wartość produkcji }\end{array}$ & 39,9 & 269 & 19.3 & 31.0 & 37.7 & 54,0 & 429 & 206 \\
\hline $\begin{array}{l}\text { wartości dodanej } \\
\text { netto z dopłatami* }\end{array}$ & 111,5 & 81,6 & 37,8 & 101,7 & 70,0 & 113,4 & 87,5 & 36,8 \\
\hline $\begin{array}{l}\text { dochodu z gosp. } \\
\text { z dopłatami* }\end{array}$ & 182,5 & 167,0 & 43,7 & 154,5 & 85,9 & 132,7 & 99,3 & 41,1 \\
\hline $\begin{array}{l}\text { Dochód z gospodarstwa } \\
\text { bez dopłat, EUR/gosp. }\end{array}$ & -19685 & -12621 & 17613 & -12480 & 2640 & -4386 & 43 & 2335 \\
\hline $\begin{array}{l}\text { Dochód z gospodarstwa } \\
\text { z dopłatami, EUR/gosp. }\end{array}$ & 23858 & 18827 & 31301 & 22887 & 18724 & 13406 & 5920 & 3967 \\
\hline
\end{tabular}

Większe uzależnienie od dopłat uwidoczniło się w przypadku ich udziału w generowaniu wartości dodanej netto (WDN), będącej jedną z tworzonych w ramach działalności operacyjnej nadwyżek ekonomicznych. $Z$ obliczeń wynika, że relacja dopłat do WDN liczonej łącznie z dopłatami wynosiła od 36,8\% w Rumunii do 113,4\% w Irlandii. W trzech krajach (Irlandia, Francja i Wielka Brytania) dopłaty przewyższały WDN ujęta łącznie z dopłatami, oznacza to, że w pewnym stopniu służyły pokryciu strat ponieważ koszty były wyższe od wytworzonej wartości produkcji. W gospodarstwach polskich udział dopłat w WDN liczonej łącznie z dopłatami wynosił $87,5 \%$, w efekcie zajęly one pozycję czwartą od końca.

Jeszcze większe uzależnienie widoczne jest w przypadku dochodu. Relacja dopłat do dochodu $\mathrm{z}$ gospodarstwa liczonego łącznie $\mathrm{z}$ dopłatami zawierała się $\mathrm{w}$ granicach od $41,1 \%$ w Rumunii do 182,5\% we Francji. W czterech krajach (Francja, Niemcy, Wielka Brytania i Irlandia) dopłaty przewyższały dochód $\mathrm{z}$ gospodarstwa łącznie ze wsparciem dopłat. Oznacza to, że produkcja w tych krajach była niedochodowa. W gospodarstwach polskich dopłaty w dochodzie liczonym łącznie z dopłatami stanowiły $99,3 \%$, co oznaczą piąta pozycję od końca. 
Siła oddziaływania dopłat na wyniki gospodarstw warunkowana jest wartością nadwyżek ekonomicznych uzyskanych $\mathrm{z}$ produkcji oraz kwot otrzymanych dopłat. Dopłaty ewidencjonowane na poziomie gospodarstwa rolnego mają znaczący wpływ na ostateczną wysokość dochodu, jednak jego wzrost nie wynika z poprawy efektywności produkcji rolnej.

\section{Podsumowanie}

Główni producenci wołowiny w Unii Europejskiej to kraje „starej Unii” (Francja, Niemcy, Włochy, Wielka Brytania, Hiszpania i Irlandia). Wśród krajów zaliczanych do UE-N13 najwięcej wołowiny produkuje Polska i Rumunia. Średnio w latach 2010-2015 w unijnej produkcji wołowiny Polska zajmowała miejsce siódme (po Irlandii), a Rumunia trzynaste. Wyniki ekonomiczne gospodarstw specjalizujących się w chowie bydła rzeźnego w wymienionych krajach były różne. Wyposażenie w czynniki produkcji także różniło się. Najmniej zróżnicowane były zasoby pracy - tylko 1,4-krotnie. Natomiast różnice w pracochłonności produkcji były większe, na 100 ha UR najwięcej tego czynnika produkcji przypadało w Rumunii - 21,43 AWU, a najmniej we Francji - 1,37 AWU. Największymi zasobami ziemi (109,76 ha) dysponowały gospodarstwa z Francji, a najmniejszymi z Rumunii (6,07 ha), zróżnicowanie było 18,1-krotne. W aktywach ogółem przeważały aktywa trwałe, ich udział wynosił od 62,3\% we Włoszech do 91,7\% w Irlandii.

Wartość dodana netto (bez dopłat) odzwierciedla opłatę czynników wytwórczych bez względu na to kto jest ich właścicielem. W trzech krajach była ona wartością ujemna. Największą stratę poniosły gospodarstwa francuskie (-4,5 tys. EUR/gosp.), strata jednostek z Irlandii była mniejsza o 53,3\%, a z Wielkiej Brytanii o 87,1\%. Oznacza to, że zwrot $\mathrm{z}$ zaangażowania czynników $\mathrm{w}$ proces produkcji nie został zrealizowany. W pozostałych krajach dochodowość czynników produkcji najniższa była w Polsce, w najwyższa: ziemi i pracy - we Włoszech, a kapitału w Rumunii.

Sprawność ekonomiczna produkcji oraz dochodowość nakładów środków obrotowych nie wykazywała związku $\mathrm{z}$ powierzchnią użytków rolnych. Najniższa była w gospodarstwach w Irlandii i Wielkiej Brytanii, a najwyższa - we Włoszech i Rumunii. Ponadto w gospodarstwach we Francji, Niemczech, Wielkiej Brytanii i Irlandii koszty były wyższe od wytworzonej produkcji, w efekcie dochód bez dopłat był wartością ujemną. Stratę pokryły dopłaty, miały też wpływ na ostateczną wysokość dochodu, jednak jego relatywnie wysoki poziom nie wynikał z wysokiej efektywności produkcji.

W literaturze omawiany jest wpływ dopłat na wyniki gospodarstw. W badaniach przeprowadzonych w kilku krajach EU-15, Zhu i Lansink (2010) oraz Zhu i inni (2012) wykazali negatywny wpływ dopłat na wydajność techniczną. Do podobnych wniosków doszedł Cechura i inni (2017) w badaniach obejmujących gospodarstwa mleczne z 24 krajów UE. Ponadto badania Dudu i Smeets Kristkovej (2017) wykazały, że dopłaty z II filaru WPR: do inwestycji w kapitał rzeczowy, rozwój kapitału ludzkiego oraz programy rolnośrodowiskowe zwiększają produktywność w rolnictwie, natomiast płatności związane z rozwojem obszarów wiejskich nie mają znaczącego wpływu na produktywność. 


\section{Literatura}

Cechura, L., Grau, A., Hockmann, H., Levkovych, I., Kroupova, Z. (2017). Catching up or falling behind in European Agriculture - the case of milk production. Journal of Agricultural Economics, 68 (1), 206-227.

Czyżewski, A., Henisz-Matuszczak, A. (2007). Sprawność ekonomiczna gospodarstw rolnych w wybranych regionach Unii Europejskiej i Polski. Próba oceny (Economic efficiency of agricultuiral farms in the chosen regions of the European Union and Poland. The trial of estimation). Folia Universitatis Agriculturae Stetinensis. Oeconomica, 47, 49-58.

Dabbert, S., Braun, J. (2012). Landwirtschafliche Betriebslehre: Grundwissen Bachelor, 3 Auflage, Ulmer UTB, Stuttgart.

Dudu, H., Smeets Kristkova, Z. (2017). Impact of CAP Pillar II payments on Agricultural Productivity. JCR Technical Reports, European Commission.

European Commission (2016). EU agricultural outlook prospect for the EU agricultural markets and income 2016-2026, December 2016.

European Commission (2018). EU Meat Market Observatory. Pobrano 22 stycznia 2018 z: https://ec.europa.eu /agriculture/market-observatory/meat_en.

European Parliament, Directorate-General for Internal Policies (2017). Research for Agri Committee - the EU cattle sector: challenges and opportunities - milk and meat.

Farm Accountancy Data Network (2017). Pobrano 11 listopada 2017 z: http://ec.europa.eu/agriculture/rica.

Goraj, L., Mańko, S. (2004). Systemy monitorowania sytuacji ekonomicznej i produkcyjnej gospodarstw rolnych (Systems of monitoring the economic and production situation of farms). W: Rachunkowość rolnicza. Warszawa, Difin.

GUS (2011). Zwierzęta gospodarskie w 2010 r. (Farm animals in 2010). Warszawa.

GUS (2017). Zwierzęta gospodarskie w 2016 r. (Farm animals in 2016). Warszawa.

Kulawik, J. (2007). Wybrane aspekty efektywności rolnictwa (Selected aspects of agricultural efficiency). Zagadnienia Ekonomiki Rolnej, 1, 3-16.

Kulawik, J. (red.). (2013). Dopłaty bezpośrednie i dotacje budżetowe a finanse oraz funkcjonowanie gospodarstw i przedsiębiorstw rolniczych (Direct payments and budget subsidies versus finances and functioning of farms and agricultural enterprises) (3). Monografia Programu Wieloletniego 2011-2014, IERiGŻ-PIB, 82.

Nogalski, Z., Wroński, M. (2011). Doskonalenie technologii opasu bydła (Improving bovine fattening technology). Przeglad Hodowlany, 4, 17-20.

Pasińska, D. (2016). Rynek wołowiny (The beef market). W: Sytuacja na światowych rynkach mięsa i produktów mleczarskich oraz jej wpływ na rynek krajowy i możliwości jego rozwoju. Monografia Programu Wieloletniego 2015-2019, IERIGŻ-PIB, nr 31, 13-24.

Rycombel, D., Zawadzka, D., Wierzbicka, A. (2012). Sytuacja na światowym rynku wołowiny i jej wpływ na polski sektor wołowiny (The situation on the global beef market and its impact on the Polish beef sector). Monografia Programu Wieloletniego 2011-2014, IERIGŻ-PIB, nr 36.

Woś, A. (1996). Agrobiznes. T. 2. Mikroekonomika (red.) (Agribusiness. T. 2. Microeconomics). Warszawa. Wyd. Key Text.

Zhu, X., Demeter, R.M., Lansink, A.O. (2012). Technical efficiency and productivity differentials of dairy farms in three EU countries: the role of CAP subsidies. Agricultural Economics Review, 13(1), 66-92.

Zhu, X., Lansink, A.O. (2010). Impact of CAP subsidies on technical efficiency of crop farms in Germany, the Netherlands and Sweden. Journal of Agricultural Economics, 61(3), 545-564.

Do cytowania / For citation:

Skarżyńska A. (2018). Wykorzystanie czynników produkcji w gospodarstwach specjalizujących się w chowie bydła rzeźnego w wybranych krajach Unii Europejskiej. Problemy Rolnictwa Światowego, 18(2), 280-290; DOI: 10.22630/PRS.2018.18.2.55

Skarżyńska A. (2018). The Use of Production Factors in Farms Specializing in Production of Fattening Cattle in Selected European Union Countries (in Polish). Problems of World Agriculture, 18(2), 280-290; DOI: 10.22630/PRS.2018.18.2.55 